\title{
EKSISTENSI SENI HIAS RUMAH TRADISIONAL KUDUS
}

\author{
Arif Suharson ${ }^{1}$ \\ (Program Doktor ISI Surakarta, arifsuharson318@gmail.com) \\ Dharsono ${ }^{2}$ \\ (ISI Surakarta, eyangdharso@gmail.com) \\ Bambang Sunarto 3 \\ (ISI Surakarta, bsunarto432@gmail.com) \\ Nanik Sri Prihatini ${ }^{4}$ \\ (ISI Surakarta, naniksriprihatini53@gmail.com)
}

\begin{abstract}
This study aims to understand the existence of Kudus traditional house decorative art that is formed in conjunction with the culture that enters the cultural life of the Kudus people. The presence of decorative art has an important meaning for the community because it is closely related to the noble values that become a learning vehicle for the next generation. Decorative art in Kudus traditional house made with a variety of decorative diversity that is behind it is a form of strong cultural perspective. The decorative art is deliberately made to have beautiful forms of stilisasi, magnificent but also related to the meaning of symbols. Grounded research with three steps of activity simultaneously, namely: data reduction, data presentation, and verification or withdrawal of conclusions with inter-pretative model analysis conducted to produce valid research. As a result of human culture, the phenomenon of artifacts is certainly inseparable from the sociocultural context in art. The decorative art of Kudus traditional house characterized by coastal culture was born with the strengthening of socio-economic progress of the community with the concept of "gusjigang" "bagus, ngaji, and dagang" that upholds the values of teachings in Islam.
\end{abstract}

Keywords: decorative art, Kudus house, culture

ABSTRAK
Penelitian ini memiliki tujuan untuk memahami eksistensi seni hias rumah tradisional Kudus yang terbentuk bersamaan dengan budaya yang masuk dalam kehidupan budaya masyarakat Kudus. Kehadiran seni hias memiliki arti penting bagi masyarakat karena berkaitan erat dengan nilai-nilai luhur yang menjadi wahana pembelajaran bagi generasi penerusnya. Seni hias pada rumah tradisional Kudus yang dibuat dengan keberagaman ragam hias yang melatarbelakanginya merupakan wujud perspektif budaya yang kuat. Seni hiasnya sengaja dibuat agar memiliki bentuk-bentuk stilasi yang indah, megah, tetapi juga berkaitan dengan makna simbol. Pendekatan grounded research dengan tiga langkah kegiatan secara bersamaan, yaitu: reduksi data, penyajian data, dan verifikasi atau penarikan simpulan dengan analisis model interpretatif dilakukan untuk menghasilkan penelitian yang valid. Sebagai hasil kebudayaan manusia, fenomena artefak ini sudah barang tentu tidak dapat dipisahkan dari konteks sosiokultural dalam berkeseniannya. Seni hias rumah tradisioal Kudus yang bercirikan budaya pesisiran lahir dengan menguatnya kemajuan sosial ekonomi masyarakat dengan konsep "gusjigang" "bagus, ngaji, dan dagang" yang memegang teguh nilai-nilai ajaran dalam agama Islam.

Kata Kunci: seni hias, rumah Kudus, budaya 


\section{PENDAHULUAN}

Keberadaan rumah tradisional Kudus tidak dapat dipisahkan dari sejarah terbentuknya kota Kudus dan tokoh yang bernama Ja'far Shadiq yang sekarang kita kenal sebagai Sunan Kudus. Sebelum menjadi kota Kudus wilayah ini bernama kota Tajug, yaitu salah satu daerah yang berada di tepi Sungai Gelis di pulau Muria. Tajug diambil dari bentuk atap rumah tradisional di masa lampau yang memiliki bentuk lancip menyerupai bentuk cungkup yang digunakan untuk tempat bersembahyang umat Hindu pada waktu agama Islam belum masuk ke daerah tersebut. Dengan demikian, kota Tajug dulunya sudah memiliki sifat kekeramatan tertentu. Pemberian nama kota Kudus yang memiliki arti suci yang diambil dari bahasa Arab yaitu Al Quds disematkan oleh Sunan Kudus (Ja'far Shadiq) sebagai bentuk penghormatan dan tidak meninggalkan kekeramatan dan sucinya kota Tajug. (Ashadi, 2010).

Rumah tradisional Kudus yang banyak terdapat di wilayah Kudus Kulon merupakan warisan budaya tradisional hasil ekspresi kesadaran masyarakat personal dan komunal dalam mengaktualisasikan gagasan, cara pandang, serta jalan hidup. Konsep "gusjigang", yaitu bagus, ngaji dan dagang yang akhirnya melahirkan konsep pembuatan rumah tradisional Kudus yang memiliki ciri khas "joglo pencu" dengan bentuk ornamen berkonsep Islam. Secara kultural daerah Kudus Kulon memiliki identitas budaya tersendiri yang sangat unik dan khas, berbeda dengan Kudus Wetan. Penyebutan wilayah Kudus Kulon dan Kudus Wetan bukanlah batasan geografis dari pemerintah, namun merupakan sebuah batasan kultural (Said, 2012). Masyarakat yang memiliki pekerjaan sebagai petani, pedagang, dan ulama berdomisili di Kudus Kulon atau termasuk golongan santri pedagang yang dikenal dengan santri saudagar. Adapun masyarakat yang disebut sebagai kaum ningrat, bangsawan, para priyayi, guru-guru dan cendekiawan bertempat tinggal di daerah Kudus Wetan.

Keberadaan rumah tradisional Kudus berdasarkan data sejarah, dan data penelitian menyebutkan bahwa rumah tradisional Kudus telah ada sejak tahun 1500-an Masehi. Peninggalan arkeologis yang ada di Kota Kudus yang diperkuat dengan data-data Tim Peneliti Hari Jadi Kota Kudus, Jurusan Sejarah, Fakultas Sastra, Universitas Gadjah Mada Yogyakarta (1990) menyimpulkan bahwa keberadaan kota Kudus sudah ada pada abad XV dengan hadirnya pemukiman yang bercorak Islam, yakni berdasarkan bukti artefak berupa sengkalan memet pada bangunan Langgar Dalem yang menunjukkan angka tahun 863 $\mathrm{H}$ atau $1458 \mathrm{M}$. Bukti prasasti yang ada di atas mihrab masjid Menara Kudus menjelaskan bahwa negeri Kudus pada waktu itu masih merupakan pemukiman yang kecil, sedangkan sebagai pemukiman perkotaan terjadi pada abad XVI (Nugroho, Y.T, 2014).

Artefak yang ditemukan berupa simbol yang berbentuk gambar trisula yang dililit naga (trisula pinulet naga) merupakan candra sengkala yang menunujukkan angka tahun $863 \mathrm{H}$ bertepatan dengan $1458 \mathrm{M}$ terdapat di Masjid Langgar Dalem, Desa Langgar Dalem, Kecamatan Kota. Simbolisasi ini memiliki bentuk gambar yang agak rumit untuk ditafsirkan artinya. Tulisan kaligrafi berbahasa Arab menjadi bukti lain berwujud batu pualam yang direkatkan pada dinding bagian atas mihrab Masjid Menara Al-Aqsha. Inskripsi yang masih jelas terlihat di atas mihrab Masjid Al-Aqsha Kudus tersebut dengan angka 956 Hijriah atau 1549 M. Inskripsi ini memberikan data sumber informasi nama kota Kudus, pendirian masjid dengan nama masjidnya, pemberian nama Menara Kudus, dan mengenai kapan pembuatannya dengan 
nama tokoh kota Kudus. Bukti menguatkan yang lain adalah bentuk prasasti dengan tulisan aksara Jawa berupa sengkalan yang berbunyi "gapuro rusak ewahing jagad wong ngarungu" berarti angka tahun Jawa 1609 yang sama dengan angka $1687 \mathrm{M}$ terdapat pada blandar Menara Kudus (lindrahti, 2012).

Keberadaan kota Kudus dengan golongan masyarakat elite yang bertempat tinggal di wilayah Kudus Kulon yang didiami oleh golongan para kyai dan saudagar kaya pada masa pemerintahan kerajaan Demak sangatlah terkenal. Hal ini dapat dibuktikan dengan rumah-rumah besar yang dikelilingi oleh tembok-tembok tinggi layaknya sebuah tempat tinggal pangeran di sebuah keraton. Gambaran masyarakat kota dengan ekonomi tingkat atas yang ditunjukkan melalui bentuk seni hias yang mewah dengan bahan baku kayu jati yang berkualitas. Seni hias yang diwujudkan dalam bentuk ornamentasi pada dinding kayu yang akrab disebut sebagai gebyok. Gebyog berukir dibuat dengan ragam hias yang indah, unik, ngremit atau rumit, spesifik, dan memiliki ciri khas, sehingga terkenal dengan sebutan rumah tradisional Kudus (Gustami, 2000). Melalui dinding kayu itu tersirat suatu keinginan untuk menunjukkan kemampuan dan keterampilan merakit panil-panil dinding kayu dan elemen bangunan lainnya yang didukung oleh hiasan berukir berkualitas tinggi. Oleh para kriyawan ukir, dinding kayu itu dihiasi dengan ukir-ukiran yang rumit, ngremit, dan ngrawit. Dindingdinding berukir itu disebut gebyok Kudus. Pada bagian tertentu, ukiran gebyok Kudus dibuat krawangan atau berlubang tembus pandang, sehingga lebih memperindah penampilannya (Stutterheim, 1926). Keberadaan seni hias dalam bentuk ukiran pada kayu dengan teknik krawangan sangat berpengaruh pula pada penciptaan seni hias wuwungan gerabah pada atap rumah tradisional Kudus yang dapat dipastikan keberadaannya tidak berdiri sendiri tetapi memiliki keterkaitan erat dengan penciptaan seni ukirnya (lihat gambar 1).

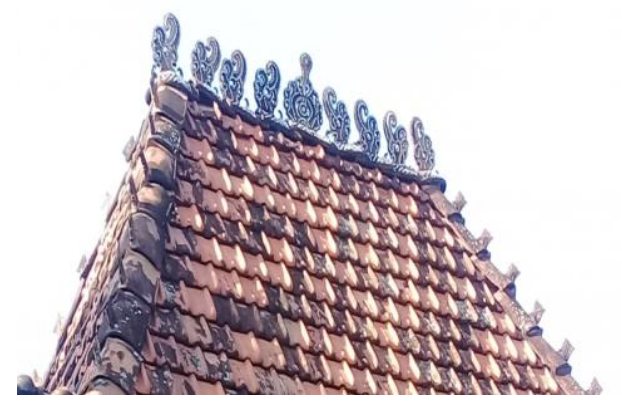

Gambar 1. Seni Hias wuwungan pada atap rumah tradisional Kudus "joglo pencu" yang juga dibuat krawangan atau tembus pandang dengan teknik inlay menggunakan pecahan beling pada bodi gerabah yang menjadi salah satu ciri khas seni hias Kudus (pesisiran).

Perkembangan zaman yang disertai dengan datanganya pengaruh internal dan eksternal dari berbagai budaya serta ideoloogi yang masuk di wilayah Kudus membuat perubahan besar dalam menciptakan bentuk arsitektur baru. Hal ini juga didukung dengan kemajuan tingkat ekonomi masyarakat terutama golongan pedagang yang memiliki andil terbesar dalam membuat perubahan, khususnya dalam pembuatan rumah tradisional Kudus. Hadirnya perpaduan konsep bangunan rumah dengan gaya Jawa (Hindu) dipadupadankan dengan pengaruh Cina (Islam) dengan sentuhan bangunan gaya Barat (Eropa), sehingga muncul rumah tradisional Kudus yang menggunakan material bahan baku utama dari kayu jati pilihan. Kayu-kayu jati tersebut dipenuhi dengan ukiran dan dipadupadankan dengan material tanah liat (gerabah/terakota) dari unsur batu bata, genteng, dan seni hiasnya. Rumah dibuat besar dan memiliki pintupintu dan daun jendela yang juga besar terinspirasi bangunan rumah loji bergaya 
Eropa. Gaya dan elemen bentuk seni tersebut seolah melebur menjadi satu bentuk arsitektur baru yang memiliki ciri khas.

Rumah tradisional Kudus "jog/o pencu" dengan berbagai bentuk seni hiasnya menjadi sarana komunikasi budaya, baik secara personal dan komunal sebagai aktualisasi masyarakat Kudus yang memiliki kekuatan ekonomi. Keberadaan seni hias yang ada di wilayah Kudus adalah kreasi ukiran yang dibuat oleh komunitas masyarakat yang sangat taat menjalankan ibadah dan syariat agama Islam. Dalam membuat seni ukiran tersebut tampaknya ada hubungan erat antara ketaatan mereka beribadah dengan kecintaan dan ketekunan melakukan kegiatan profesinya sebagai ahli ukir. Oleh karena itu, terjadilah gaya stilasi yang mantap pada seni ornamen mereka yang juga mencirikan ornamen khas Pesisir. Pada kenyataannya, perilaku dan pola hidup mereka yang memeluk agama Islam berpengaruh kuat pada hasil seni ukir. Seni ukir yang diciptakan memiliki pandangan, tata nilai, dan kegiatan hidup sehar-hari yang agamis dan penuh dengan pesanpesan moral.

\section{METODE}

Penelitian kualitatif ini memiliki tujuan untuk memahami keberadaan rumah tradisional Kudus dengan segala elemen bentuk seni hias yang dapat dijadikan sebagai pengetahuan ilmiah. Baik untuk dunia akademisi, praktisi, dan masyarakat umum yang bersifat informasi dari kajian ilmiah untuk dapat menjadi rujukan tentang kekayaan seni ornamentasi Jawa. Melalui perspektif estetika, penelitian ini tidak hanya ditujukan untuk menyingkap aspek visual bertalian dengan jenis, bentuk, karakteristik, dan gaya semata. Tujuan yang juga penting diungkap adalah pandangan hidup atau gagasan sentral yang mendasari kreasi simboliknya.
Pengungkapan demikian diharapkan dapat meningkatkan pemahaman tentang praktik kreasi artisitik dan simbolik yang ada pada seni hias rumah tradisional Kudus. Sebagai sebuah karya seni, seni hias tersebut memiliki akar sejarah yang panjang, baik dalam penciptaanya maupun pemanfaatannya di lingkungan masyarakat Kudus. Eksistensinya hingga kini tidak dapat dilepaskan dari sejarah asal-usul dan perkembangannya. Diyakini bahwa di dalam penciptaan ornamen mengandung maksud dan tujuan dengan ajaran-ajaran luhur yang dapat diterapkan dalam pengembangan seni rupa modern serta dalam membangun karakter kepribadian masyarakat Indonesia.

Pelaksanaan penelitian dilakukan dengan teknik pengumpulan data secara langsung terhadap objek kajian dengan data sumber aslinya dan juga dengan tidak langsung dengan data-data penelitian sebelumnya. Data sumber asli atau langsung menjadi data primer dan data dari sumber tak langsung menjadi sumber skunder. Metode pengumpulan data yang dilakukan agar memperoleh validitas data penelitian yang dilakukan dengan berbagai tahapan, yaitu (1) Studi Pustaka (Library Research) ditempuh dengan mencari data berupa data dokumentasi tertulis yang dapat berupa buku-buku, artikel ilmiah, jurnal, prosiding, dan penelitian yang pernah dilakukan dengan tema sesuai kajian penelitian yang dilakukan. (2) Kajian Lapangan melakukan observasi langsung dengan melakukan perekaman objek melalui dokumentasi foto, video dan mencatat hal-hal yang dianggap penting yang mendukung data penelitian. (3) Wawancara dengan model wawancara mendalam kepada narasumber terpilih berkaitan dengan kebutuhan penelitian. Wawancara dengan model triangulasi data sumber kepada para (pengamat, pakar, dan pengguna) untuk memperoleh data interpretatif dari hasil sarian wawancara 
yang telah dilakukan, sehingga akan didapatkan hasil penelitian yang memenuhi standar validitas dan diharapkan memperoleh sebuah konsep teori atau temuan teori baru. (4) Analisis Data dengan menggunakan analisis model interpretatif. Analisis interpretatif dengan pendekatan Grounded Research terdiri dari tiga alur kegiatan yang terjadi secara bersamaan yaitu, reduksi data, penyajian data, dan penarikan simpulan/verifikasi.

\section{PEMBAHASAN}

Melacak keberadaan sejarah rumah tradisional Kudus tidak dapat dipisahkan dari kondisi sosial budaya masyarakatnya. Masyarakat Kudus bukanlah dari golongan priyayi, akan tetapi pada masa pemerintahan Kolonial Belanda memberikan gelar kepada priyayi Kudus kepada aristokrat yang merupakan keturunan Sunan Kudus. Meskipun disebut priyayi, namun tata cara kehidupan mereka sangat berbeda dengan kehidupan para priyayi di daerah lain. Pada awalnya priyayi Kudus Kulon bukanlah orang kaya. Mereka bekerja sebagai pedagang, perajin, atau mubalig. Melalui pekerjaan sebagai pedagang dan pengusaha yang santri, sholeh, dan handal, yang diikuti dengan gaya pola hidup yang sederhana, selalu bekerja keras untuk mencapai tujuan hidup yang lebih baik. Dengan pola hidup yang demikian, akhirnya orang Kudus Kulon dapat mencapai kesuksesan sebagai saudagar kaya yang kemudian dapat membangun rumah yang besar dan seni hias yang megah sebagai simbol atas kesuksesan mereka. Pada periode puncak kemakmurannya, mereka menjelma menjadi kaum bangsawan kaya raya dan orang lain cenderung memandang berbeda dengan pekerjaan mereka yang dianggap bertentangan dengan cara kerja para pegawai priyayi dan elite priyayi (Wahyono, 2015). Mereka menyadari bahwa pekerjaan sebagai pedagang atau pengusaha tersebut seringkali dipandang rendah dan tidak terhormat oleh orang lain. Maka, masyarakat Kudus Kulon sebagai pedagang atau pengusaha yang sukses kemudian membuat rumah yang bentuknya megah sebagai simbol capaian kesuksesan dalam bidang ekonomi. Dengan demikian, mereka secara tidak langsung memperoleh penghargaan dan kehormatan, seperti layaknya priyayi dari kaum bangsawan. Untuk mencapai strata tersebut, masyarakat Kudus Kulon melakukan perubahan dalam menyesuaikan diri dengan tingkat strata sosial bangsawan dengan membuat posisi lantai rumah berundak lebih tinggi, seperti yang dilakukan oleh kaum bangsawan pada umumnya. Hal lainnya adalah membuat bentuk atap rumah joglo Jawa dibuat lebih tinggi dengan seni hias wuwungan yang gemerlap (lihat gambar 2). Selain itu juga membuat pembeda dengan menampilkan visualisasi kemewahan berupa ukiran yang hampir memenuhi seluruh ruangan dan dinding rumah tradisional Kudus.

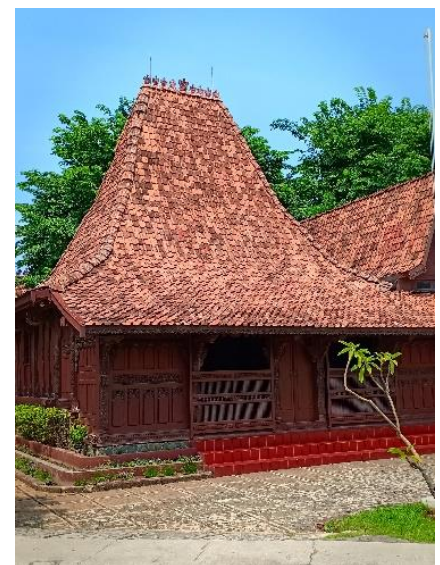

Gambar 2. Rumah tradisional Kudus "joglo pencu" yang dilengkapi dengan tangga berundak dan atap yang dibuat lebih panjang dengan seni hias wuwungan gerabah yang gemerlap.

Temuan data di lapangan menunjukkan bahwa arsitektur tradisional Kudus terdapat tiga unsur kebudayaan arsitektur terbesar yang memengaruhi 
arsitektur rumah tradisional Kudus, yaitu: 1) arsitektur Hindu dan Budha; 2) arsitektur Cina; dan 3) arsitektur Islam (Arabesh). Kemudian pada perkembangan selanjutnya dipengaruhi oleh Eropa. Perlu diketahui bahwa sudah ada komunitas Hindu yang terdapat di wilayah Kudus sebelum Demak menjadi kota yang maju dan agama Islam menguasai pesisir pantai utara Jawa. Pada masa itu, candi-candi telah banyak dibangun, salah satu contohnya adalah "Mesjid Bubar" yang terletak di jalan Madureksa, Kudus. Bangunan tersebut konon merupakan komplek bangunan pemujaan atau ibadah bagi pemeluk agama Hindu. Hal ini dibuktikan dengan keberadaan patung lingga yoni, ornament slimpetan, dan relief manusia. Dalam tampilannya, Candi Menara Kudus yang dibangun oleh umat Hindu pada waktu itu hampir sama dengan Candi Singosari dan Bale Kul-Kul di Bali, dan Lawang Kembar atau Candi Bentar sebagai gapura. Makam sunan Kudus juga menggunakan gerbang peninggalan Hindu (Siswanto, 1986).

Kebudayaan masyarakat Kudus mulai mengalami perubahan dengan masuknya pengaruh agama Islam di Jawa. Dengan demikian tumbuhlah kebudayaan baru sintesis yang dikenal dengan kebudayaan masa peralihan. Masa peralihan ini ditandai dengan meleburnya kebudayaan Hindu-Budha dengan unsur kebudayaan Islam (Mustopo, 2001). Masa peralihan juga masuk dalam ranah pemerintahan dari kerajaan Hindu-Jawa pedalaman berpindah ke kerajaan Islam Pesisiran yang dimaknai dengan peralihan nilai-nilai ajaran agama Hindu-Budha ke nilai-nilai ajaran agama Islam.

Berdirinya kerajaan Demak yang bernafaskan agama Islam bersamaan dengan surutnya kerajaan Jawa-Hindu Majapahit pada tahun 1518 M disebut sebagai zaman peralihan. Zaman peralihan tersebut adalah peralihan zaman dari pengaruh agama Hindu-Budha yang disebut sebagai zaman Kabudan berubah ke zaman pengaruh agama Islam sebagai zaman Kuwalen. Penyesuaian dengan zaman peralihan Islam ini bukan berarti pembuangan dan pergantian makna tradisi seni budaya adiluhung warisan kerajaan Jawa-Hindu, namun memiliki sifat pengislaman (Simuh, 1995).

Periode Jawa-Hindu tersebut dan pada masa awal perkembangan agama Islam di Kudus sudah dikenal tanah liat yang dibakar dan batu andesit, namun rumah penduduk tidak menggunakannya sebab bahan bata ini dianggap isitimewa dan hanya digunakan untuk dewa-dewa atau bangunan candi atau bangunan sakral. Rumah rakyat pada umumnya menggunakan kayu sebagai bahan utamanya dan genting sudah mulai digunakan menggantikan atap rumbia (Sumono, 1989).

Keberadaan rumah tradisional Kudus juga tidak dapat dipisahkan dengan keberadaan runtuhnya Kerajaan Majapahit dan kemunculan Kerajaan Demak. Pada masa ini banyak terjadi perubahan dalam tatanan kehidupan sosial yang terjadi pemerosotan budaya Majapahit dan banyak masyarakat Majapahit (Cina-Islam) yang akhirnya melakukan perpindahan tempat secara besar-besaran menuju ke Demak. Alih teknologi dan pengetahuan budaya baru yang datang ke wilayah Demak dan menyebar pula di wilayah Jepara, Kudus, dan Pati. Terjadilah perpaduan budaya yang akhirnya memunculkan budaya Pesisir karena pengaruh para pendatang dengan bermunculan karya-karya seni baru. Rumah tradisional Kudus dengan segala unsur seni hias yang akhirnya memiliki atap yang tinggi dan besar, dahulunya juga hanya berbentuk rumah-rumah Jawa pada umumnya.

Ukiran-ukiran yang menghiasi pada dinding-dinding rumah juga belum dipenuhi dengan ukiran yang banyak. Seni hias yang 
diterapkan hanya sebagai ornamentasi biasa, maksudnya tidak semua ruangan diberi ornamen. Lantai-lantai rumah juga hanya biasa tidak memiliki posisi yang ditinggikan dengan hadirnya bancik atau tangga menuju ruang utama yang posisinya agak dibuat lebih tinggi. Walau demikian seni ornamen tetap memiliki nilai filosofi yang syarat dengan makna. Ragam hiasnya masih banyak mengacu dari ide penciptaan bentuk relief-relief yang ada pada candi, yakni ornamen yang ada pada kompleks masjid Menara Kudus dan kompleks makam di belakang masjid menjadi bukti kuat. Salah satu contoh unsur ragam hias budaya Hindu tersebut adalah ornamen pancuran atau tempat wudhu yang ada pada kompleks masjid Menara Kudus (lihat gambar 3)

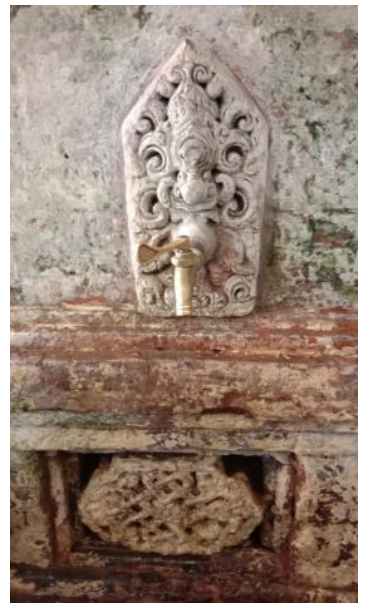

Gambar 3. Ragam Hias Kala dan Medalion pada Masa Hindu yang Terdapat pada Tempat Wudhu Kompleks Masjid Menara Kudus

Berdasarkan wawancara dengan beberapa tokoh masyarakat dan hasil data penelitian yang telah dilakukan oleh peneliti-peneliti sebelumnya paling tidak ada tiga kategori rumah tradisional Kudus yang dapat diklasifikasikan, yaitu:

1. Rumah Adat Biasa, yaitu rumah tanpa ukiran atau dengan ukiran minimal, namun menonjolkan bahan yang digunakan dari kayu jati

pilihan. Rumah adat dalam kelompok ini merupakan generasi pertama yang muncul sekitar abad ke-15;

2. Rumah Adat Berukir Sebagian, yaitu rumah yang memiliki sebagian ukiran yang terdapat pada sudutsudut tertentu. Hal ini seperti tampak pada tiang, pintu, atau pada panil-panil gebyok-nya. Kemunculan rumah adat berukir sebagaian ini hampir bersamaan dengan kelompok pertama, yaitu abad ke-16-17;

3. Rumah Adat Berukir Sempurna, yaitu rumah adat dengan menonjolkan ornamen ukiran yang penuh dan padat hampir di setiap bagian ornamen pada rumah tradisional Kudus. Seni hias yang diterapkan dalam bentuk seni ukir sangat sempurna, bahkan sampai ke bentuk tembus pandang tiga dimensi. Kemunculan seni hias ini diperkirakan sejak abad ke-17 sampai 18, terutama ketika para pengusaha mencapai puncak kesuksesannya dalam berdagang.

Keberadaan rumah tradisional Kudus berdasarkan hasil kajian dari Prof. Dr. Supardi Suparlan (antropolog) yang mengatakan bahwa seni ukir pada rumah tradisional Kudus memiliki 3 aliran jenis ukir yang dicetuskan oleh ketiga tokoh pendekar seni ukir yang berkembang sampai sekarang. Tiga aliran ukir dari tokoh besar itu adalah aliran ukir Rogomoyo, aliran ukir Rogojati, dan aliran ukir Rogojoyo yang hasil ukirannya memiliki karakter dan nilai-nilai filosofi kearifan lokal berdimensi universum. Karena nilai-nilai ini dicintai dan dikenal di semua peradaban kehidupan 
manusia, terutama masyarakat Kudus. Bahkan rumah tradisional Kudus ukirannya dicipta dan dibuat dengan pendekatan antroposintesis (wawancara dengan Sumarno, Dosen UNNES Semarang). Aliran seni ukir dari tiga tokoh Rogomoyo, Rogojati, dan Rogojoyo dapat dibedakan dari ukuran dan kualitas perpaduan seni ukirnya. Ketiga tokoh ini merupakan murid dari ahli ukir The Ling Sing dan Sung Ging An yang berasal dari Cina (Islam) yang namanya diabadikan sebagai salah satu nama desa ahli ukir, yaitu Sunggingan di wilayah Kudus.

Ukiran aliran Rogomoyo masih bersifat sederhana, tidak rumit, bentuk besar-besar, dan motif ukirannya klasik, seperti misalnya bunga teratai, melati, telasih, sulur-suluran, dan bunga lainnya yang berhubungan dengan persembahyangan atau sarana untuk ibadah. Pada ukiran aliran Rogomoyo motif binatang masih tergambar dengan jelas belum mengalami banyak penggayaan. Ukiran aliran Rogojati mulai tampak lebih rumit dan minimal sudah memiliki dua dimensi. Motif binatang sudah mulai disamarkan dan distilisasi sedemikian rupa. Meskipun demikian, ukirannya masih berukuran besar-besar dan pengaruh budaya Cina sudah masuk dalam ragam hias seni ukiran. Hal ini dibuktikan dengan adanya simbol-simbol berbentuk bokorbokor, lambang binatang mitologi (kilin, burung hong, dan awan) dan swastika. Sedangkan ukiran aliran Rogojoyo banyak mengadopsi ide-ide dari ukiran aliran dua tokoh sebelumnya. Hasil ukiran aliran Rogojoyo dapat dikatakan sebagai penyempurnaan ukiran Kudus yang dibuat sangat rapi, motif kecil-kecil, halus, dan berdimensi 3 hingga 4 lapis terkesan sangat mewah, detail dan ngremit atau rumit.

Masyarakat Kudus yang sebagian besar menjadi saudagar santri merupakan masyarakat penganut Islam puritan sebagaimana dicontohkan oleh Sunan Kudus. Konsep hidup "Gusjigang" yang merupakan kependekan dari Bagus, Ngaji dan Dagang memberikan gambaran nyata pola berpikir masyarakat Kudus yang mengacu pada ajaran agama Islam (Sardjono, 2017 ). Peranan penting dalam otoritas soisal ekonomi dan politik dipegang teguh oleh para wali. Para wali memegang peranan tersebut sangat berbeda dengan pola pemikiran kaum bangsawan Majapahit. Ajaran Islam melalui wali ini mengajarkan dengan tegas kepada masyarakat Kudus agar mereka tidak menggambarkan makhluk bernyawa dalam seni hias termasuk di dalamya seni hias rumah tradisional Kudus. Bahkan dengan tegas melarangnnya karena bertentangan dengan ajaran agama Islam. Seni ornamen dihadirkan dengan tidak menggambarkan makhluk bernyawa secara realistis. Tetapi wajib dilakukan penggayaan bentuk dengan membuat stilisasi yang menggabungkan unsur-unsur budaya yang ada menjadi padu, tetapi tetap menguatkan ciri khas ornamen Kudus.

Ragam hias yang muncul pada ornamen rumah tradisional Kudus pada umumnya mempertahankan gaya ornamen pada masa Hindu dan Budha. Hal ini terkait dengan nilai simbolis yang masih diaplikasikan pada unsur ornamen yang syarat dengan ajaran dan kepercayaan agama, walaupun sudah masuk pengaruh Islam (Cina) keberadaanya tetap paling menonjol. Ornamen digambarkan dalam bentuk visual yang digarap secara indah, halus, ngremit, luwes, lemah gemulai, dan sangat tertib struktur penyusunannya. Penggambaran sosok manusia yang dijadikan motif hias sudah digambarkan tidak kaku yang melambangkan sosok nenek moyang dengan berbagai sikap dan 
kelengkapan atributnya. Dengan pengaruh Islam (Cina) yang ada, sosok manusia digambarkan lebih dekoratif dengan tambahan seni hias yang padat pada tataran teknik ukir ukir ngremit, rumit, memiliki kesan bergradasi, dan indah.

Penerapan ornamen dalam rumah tradisional Kudus juga meliputi motif-motif yang disusun berulang, penggambaranya juga mengambil ide dari unsur alam, binatang, dan juga masih tampak menggambarkan motif manusia. Sumber ide motif ini kemudian dibuat pola dengan cara meniru objek secara utuh dan ada yang dilakukan dengan penerapan stilasi yaitu dilakukan penggayaan, menambah, dan mengurangi objek motif atau polanya. Menurut Tabrani (2000), penerapan ornamen yang ada di Jawa khususnya motif-motif tradisional sesungguhnya masih erat kaitannya dengan pandangan dualisme dwi tunggal. Maksudnya adalah dalam pandangan filosofis ini menggambarkan segi yang berbeda bahkan bertentangan harus dalam keadaan satu atau dalam kesatuan. Ketika ada dunia atas dan bawah harus ada aspek lain yang menyatukannya. Demikian pula bila ada golongan kiri dan kanan harus disatukan dengan unsur ketiga setelah pemersatunya. Dengan demikian, agaknya kita memang tidak menolak pola setangkup tetapi tidak dalam susunan yang benar-benar setangkup.

Ciri khas ornamen Kudus dengan bentuk ukiran yang detail dan halus menempatkan ukiran ornamen pada rumah tradisional Kudus menjadi simbol status ekonomi pemiliknya. Unsur-unsur ornamen yang terdapat di dalamnya ditambahkan dengan muatan-muatan pesan moral penuh dengan nilai-nilai ajaran filososfi sebagai bentuk pembelajaran karakter berbudi luhur kepada generasi penerusnya. Ragam hias atau motif ukir yang diterapkan pada rumah tradisional Kudus terdiri atas berbagai motif, di antaranya yaitu:

1. Burung Hong, singa, kilin, naga, matahari, raksasa, bunga banyak diukir secara alami dan detil, sehingga hasilnya tampak sangat indah sekaligus rumit. Gaya ukiran ini juga disebut sebagai gaya ukiran Cina yang terdapat pada bancikan (lihat gambar 4). Bancikan diberi makna sebagai sarana introspeksi dan refleksi diri untuk menuju tingkatan spiritualitas yang lebih baik.

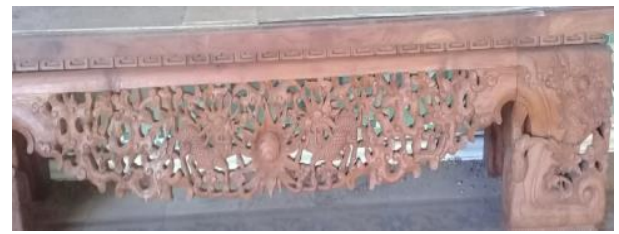

Gambar 4. Ornamen yang Terdapat pada Bancikan Menuju Ruang Dalem Rumah Tradisional Kudus

2. Daun pisang/ban-banan, ragam hias ini juga sering disebut oleh masyarakat sebagai sampar banyu. Ukiran dengan motif hias ini menjadi simbol prinsip hidup sebagai layaknya sifat pohon pisang yang tidak akan mati sebelum meninggalkan buah atau menghasilkan buah atau meninggalkan sesuatu yang bermanfaat, yaitu tunas baru (lihat gambar 5). Pesan yang terkandung dalam simbol ini adalah mengajarkan kepada semua penghuni agar selama diberi umur oleh Allah SWT hendaknya senantiasa berupaya untuk beramal yang baik atau bermanfaat bagi orang lain. 


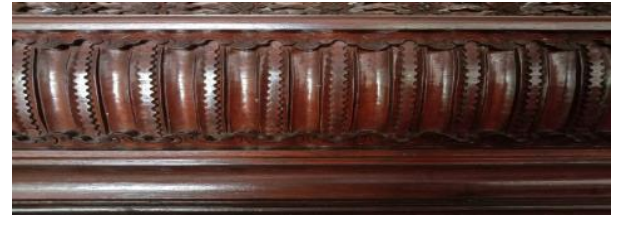

Gambar 5. Motif Ban-Banan/Sampar Banyu pada Rumah Tradisional Kudus

3. Kala dibuat stilisasi yang melambangkan sebagai penolak bala. Dalam kaitannya dengan keagamaan, kala merupakan lambang kekuatan sakti untuk menolak kejahatan (lihat gambar 6). Dalam perwujudan ukiran bentuk kala disamarkan dengan bentuk daun maupun bunga.

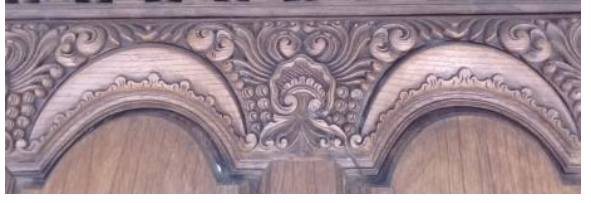

Gambar 6. Motif Ban-Banan/Sampar Banyu pada Rumah Tradisional Kudus

Ornamen atau ragam hias rumah tradisional Kudus berupa ukir-ukiran yang sangat indah, yang terdapat hampir di semua bagian rumah. Pembahasan di atas hanya beberapa contoh motif dan belum secara keseluruhan dibahas. Ragam hias ukiran rumah tradisional ini dapat kita jumpai pada dinding/gebyok, pintu utama jagasatru, blandar, saka geder, sanggan/konsul, tumpang sari, saka guru, dan kayu-kayu lain yang digunakan dalam rumah tradisional Kudus. Hasil pengamatan lapangan dengan data-data penelitian menunjukkan bahwa seni ukiran Kudus merupakan hasil olah kreatif masyarakat dengan perpaduan akulturasi budaya dalam empat dimensi.

Empat dimensi tersebut adalah 1) perpaduan budaya Hindu yang terdapat pada gebyok pembatas ruang jagasatru dan dalem/gedongan; 2) budaya Persia/Islam terwujud dalam bentuk bunga-bunga pada ruang jagasatru; 3) budaya Cina dengan munculnya motif-motif khas Cina pada bancikan/bangku kecil untuk masuk ke ruang dalem/gedongan; dan 4) budaya Eropa yang terwujud dalam bentuk crown/mahkota yang ada di atas pintu masuk dalem/gedongan.

Secara umum elemen-elemen bentuk ragam hias yang terdapat pada seni hias rumah tradisional Kudus dapat dikelompokkan menjadi: 1). Ragam hias geometris adalah suatu bentuk yang di dalamnya menggunakan pola hias garisgaris ilmu ukur. Ragam hias ini sudah lama digunakan di Indonesia sejak zaman prasejarah dan penggunaanya berlangsung pada masa-masa berikutnya. Ragam hias geometris sering terdapat pada hasil kerajinan gerabah dan anyaman. Pada masa klasik ragam hias ini banyak terdapat pada seni bangunan candi terutama masa Hindu dan Budha. Pada masa Islam ragam hias ini semakin banyak digunakan karena dalam seni Islam terdapat larangan untuk menggambarkan mahkluk hidup atau bernyawa. Ragam hias geometris ini paling umum digunakan adalah berupa motifmotif tumpal, medalion, bingkai cermin, pilin berganda, belah ketupat (wajikan), dan motif-motif seperti dalam anyaman. Dalam seni hias wuwung rumah tradisional Kudus bentuk ini berupa ragam hias wajikan, tumpal, dan belah ketupat; 2) Ragam hias tumbuh-tumbuhan/Flora di Indonesia dikenal sejak periode masa klasik. Ragam hias tumbuh-tumbuhan ini biasanya diambil dari ide tumbuh-tumbuhan yang ada pada lingkungan alam sekitar. Pada seni hias masa Islam, ragam hias tumbuh-tumbuhan selain digambarkan berdiri sendiri, juga digunakan untuk menyamarkan motif-motif lain, khususnya motif makhluk hidup. Biasanya ragam hias ini diketemukan dalam 
bentuk teratai, sulur-suluran, ukel, lung kangkung, dan bentuk tangkai, daun, dan bunga. Dalam seni hias wuwung rumah tradisional Kudus bentuk ragam hias flora distilasi dari bentuk daun yang menjadi bentuk lung, sulur-suluran, dan ukel; 3) Ragam Hias Hewan/Fauna, ragam hias binatang yang ada di wilayah pesisiran pantai utara Jawa berupa motif gajah, burung, kera, ular, naga, dan binatang berkaki empat menyerupai singa. Ragam hias ini juga terdapat pada hiasan panelpanel dan gebyok rumah Kudus yang digambarkan dalam bentuk stilasi dipadupadankan dengan stiliran sulursuluran dan bunga-bungaan. Penggambaran ragam hias binatang bukan hanya berhubungan dengan segi estetik saja, tetapi juga mengandung maksud sebagai lambang-lambang yang berhubungan dengan alam seisinya dan kepercayaan pada masanya. Pada seni hias wuwung rumah tradisional Kudus, ragam hias ini diasumsikan pada bentuk jengger ayam jago dan pada bagian penutup wuwung sudut yang dikenal dengan sebutan wuwung bulusan yang berarti mengambil ide dari hewan bulus atau binatang penyu/kura-kura; 4) Ragam Hias Manusia, ragam hias manusia tidak secara utuh digambarkan biasanya disamarkan dalam bentuk stilasi. Bentuk manusia yang ada pada ornamen rumah Kudus adalah bentuk kala atau raksasa yang dibentuk dengan stiliran daun-daunan atau sulursuluran. Juga terdapat pada tokoh-tokoh wayang yang dianggap baik yang diasumsikan dalam bentuk gelung keling dari tokoh wayang yang berjiwa pahlawan. Pada seni hias wuwung ini terdapat pada bentuk wuwung pengapit dan gelung cekak pada sisi gendeng yang menyebar ke 4 arah penjuru angin; dan 5) Ragam Hias Artifisial, ragam hias yang memiliki sifat artisial biasanya dikenal sebagai bentuk ragam hias dekoratif. Penggabungan dari beberapa inspirasi ragam hias pada kelompok yang ada sebelumnya dengan dilakukan modifikasi disebut sebagai ragam hias dekoratif, sehingga menjadi sebuah bentuk ragam hias yang baru dan memiliki nilai estetika tersendiri. Pada seni hias wuwung rumah tradisional Kudus bentuk ragam hias artifisial terdapat pada wuwung tengah yang berbentuk stilasi dari bentuk gunungan, wuwung pengapit yang juga digambarkan bentuk gelung dan suluran. Alur garis bentuk wuwung diperjelas dengan dekorasi dari pecahan beling/kaca.

\section{PENUTUP}

Eksistensi seni hias dalam produkproduk kriya dan beberapa pada arsitektur yang sering kita kenal dengan istilah ornament merupakan komponen penting yang memiliki tujuan untuk hiasan. Hiasan ini tidak hanya sekedar menghias, tetapi juga bermuatan simbolik yang syarat akan makna, baik untuk tujuan spiritual maupun material. Ornamen yang mengandung nilainilai simbolik yang ada hubungannya dengan pandangan hidup dan kepercayaan sang pembuatnya atau dalam komuitas komunal suatu wilayah masyarakat, sehingga produk karya kriya atau bangunan arsitektural yang dikenai ragam hias itu mempunyai arti yang lebih bermakna (menambah nilai bangunan).

Oleh karena itu, terjadilah gaya stilasi yang mantap pada seni ornamen mereka yang juga mencirikan ornament khas budaya pesisiran yang sangat berbeda degan hasil budaya pedalaman. Pengaruh yang datang dari luar seolah menjadi lebur bersatu padu saling memperkuat untuk menonjolkan ciri budaya pesisiran tetapi tetap terlihat unsur budaya Jawa sebagai budaya lokal yang tetap dijunjung tinggi masyarakat komunalnya. Pada kenyataannya perilaku dan pola hidup mereka yang memeluk agama Islam 
berpengaruh kuat pada hasil seni ukir. Seni ukir yang diciptakan memiliki pandangan, tata nilai, dan kegiatan hidup sehar-hari yang agamis dan penuh dengan pesanpesan moral dalam ajaran agama Islam.

\section{DAFTAR PUSTAKA}

Ashadi. (2010). Jejak Keberadaan Rumah Tradisional Kudus: Sebuah Kajian Antropologi-Arsitektur Sejarah. Nalars, 147-164.

Gustami. (2000). Seni Kerajinan Mebel Ukir Jepara, Kajian Estetika Melalui Pendekatan Multidisiplin. Yogyakarta: Penerbit Kanisius.

lindrahti, S. (2012). Kudus dan Islam: NilaiNilai Budaya Lokal dan Industri Wisata Ziarah. Semarang: CV Madina.

Mustopo, M. (2001). Kebudayaan Islam di Jawa Timur: Kajian Beberapa Unsur Budaya Masa Peralihan. Yogyakarta: Jendela.

Nugroho, Y.T, A. (2014). Budaya dan Wisata Kabupaten Kudus. Kudus: Dinas Kebudayaan dan Pariwisata Kabupaten Kudus.

Said, N. (2012). Tradsi Pendidikan Karakter Dalam Keluarga, Tafsir Sosial Rumah Adat Kuduz. Kudus: Brilian Media Utama .

Sardjono, A. (2017). Respon Rumah Tradisional Kudus Terhadap Iklim Tropis. Jurnal Modul, volume 11 no 1 Januari 2017, 16.

Simuh. (1995). Sufisme Jawa: Transformasi Islam ke Mistik Jawa. Yogyakarta: Yayasan Benteng Budaya.

Siswanto, A. (1986). Data Arsitektur Tradisional Kudus. Semarang: Dinas
Pekerjaan Umum Pemerintah Propinsi Daerah Tingkat 1 Jawa Tengah dan PT Wastuwidyawan.

Stutterheim,

W.

(1926).

Cultuurgeschiedenis van Java in

Beeld. Te Weltevreden: Uitgegeven door Het Java-Instituuten G. Kolff \& Co.,.

Sumono. (1989). Gaya Arsitektur Tradisional Rumah Adat Kudus, Rangkuman Hasil Pelaksanaan Program Inventarisasi dan Dokumen Kebudayaan. Kudus: Tidak Diterbitkan Departemen Pendidikan dan Kebudayaan Kudus.

Wahyono, T. (2015). Rumah Adat Kudus. Yogyakarta: Direktorat Internalisasi Nilai dan Diplomasi Budaya, Balai Pelestarian Nilai Budaya Yogyakarta. 